\title{
КЛЮЧОВІ СОЩАЛЬНО-ПСИХОЛОГІЧНІ ОСОБЛИВОСТІ ПОДРУЖЖЯ ЗІ СВІДОМОЮ БАГАТОДІТНІСТЮ
}

\author{
Чепелсва Надія
}

Харківський національний університет внутрішніх справ

м. Харків, Україна

chepn@ukr.net

https://orcid.org/0000-0003-2101-9571

Мета. У статті здійснено теоретичний та емпіричний аналіз окремих соціально-психологічних особливостей подружніх пар зі свідомою багатодітністю.

Методи. Теоретичний соціально психологічний аналіз феномену багатодітності щодо характеристик, які зумовлюють, сприяють свідомому вибору багатодітності подружжя. На базі теоретичного аналізу було розроблено анкету і здійснено опитування, яке включало декілька сутнісних блоків питання щодо прийняття рішення про багатодітність, щодо труднощів багатодітної родини, особливостей внутрішньосімейної та соціальної підтримки.

Результати. Теоретично й емпірично виявлені соціально-психологічні особливості людей, які свідомо стали батьками 3-х і більше дітей та відчувають у цьому своє покликання, потребу i бажання, базуються на високих репродуктивних початкових установках у більшості респондентів. 3'ясовано, що перехід сім'ї до багатодітності може здійснюватися різними етапами, але можна ствердно говорити, що усвідомлену багатодітність слід розглядати як заплановану багатодітність. Це підтверджується даними статистики й соціокультурними механізмами, за якими саме наявність 3-х і більше дітей $\epsilon$ тим рівнем, який зумовлює життєздатність суспільства і родини.

Проаналізовані дані опитування благополучних багатодітних родин, де спостерігається життєва стійкість сімейної системи, жінки займаються професійною діяльністю, самореалізовані, і при цьому поєднують материнство та виховання дітей, адже в сучасному світі цінність батьківства конкурує 3 іншими цінностями, зокрема з успішною професійною діяльністю і кар'єрою. Встановлені певні суспільні установки та стереотипи щодо багатодітності. Наведені сучасні погляди суспільства, згідно з якими призначення жінки - це не лише материнство і дім, а й інші можливості для реалізації закладеного в ній потенціалу. Основою свідомої багатодітності подружжя $є$ особистісна i соціальна зрілість його членів.

ISSN 2308-3743 (Online), ISSN 2227-1376 (Print)

(C) Чепелєва Н., 2021. Ця стаття відкритого доступу на умовах CC BY-NC 4.0 
Висновки. В роботі сформульовані соціальні і особистісні характеристики, проблеми і труднощі, з якими стикаються батьки зі свідомою багатодітністю. Доведено, що соціальна підтримка хоча й відіграє суттєву роль, але насамперед потрібно формувати іiі на базі психологічної готовності, свідомого вибору, можливостей самореалізації таких сімей і батьків зокрема.

Ключові слова: сім'я, подружжя, батьківство, психологічна готовність, самореалізація батьків.

\section{Nadiya Chepelieva. Basic social and psychological peculiarities of a couple having a conscious large family.}

Purpose. The article focuses on theoretical and empirical analysis of certain social and psychological peculiarities of married couples having conscious large families.

Methods. Theoretical social and psychological analysis of the phenomenon of a large family concerning the characteristics that determine and contribute to the conscious choice regarding a family having many children. The developed questionnaire and conducted survey are based on theoretical analysis, which includes several essential blocks: questions about the decision to have many children, difficulties of a large family, peculiarities of internal familial and social support.

Results. The social and psychological peculiarities of people who have consciously become parents of 3 or more children feel in this their call, need, and desire are based on high reproductive initial settings in most respondents are theoretically and empirically determined. It has been found out that transition of a family to have many children may have a place at different stages, but it can be argued that a conscious large family should be considered as a planned one. It is confirmed by the statistics, the social and cultural mechanisms, according to which the presence of three or more children is that level that predetermines the viability of a society and a family.

The survey data of prosperous large families have been analyzed, where the vital stability of the family system is observed; women are engaged in professional activities and are self-realized, and at the same time combine motherhood and raising children, because in the contemporary world the value of parenthood competes with other values, particularly with successful professional activity and career. Certain social settings and stereotypes regarding a large family have been determined. The contemporary viewpoints of the society are presented, according to which the function of a woman is not only motherhood and home, but also other opportunities for implementation of the potential inherent in her. The basis of a couple having a conscious large family is the personality and social maturity of its members.

Conclusions. The paper formulates social and personality characteristics, problems and difficulties faced by conscious parents having large families. It has been proved that although social support plays a significant role, first it is necessary to form it based on psychological readiness, conscious choice, opportunities for selfrealization of such families and parents in particular. 
Keywords: family, couple, parenthood, psychological readiness, self-realization of parents.

\section{Чепелева Надежда. Ключевые социально-психологические особенности супружеских пар с сознательной многодетностью.}

Цель. В статье осуществлен теоретический и эмпирический анализ отдельных социально-психологических особенностей супружеских пар с сознательной многодетностью.

Методы. Теоретический социально психологический анализ феномена многодетности, характеристики, которые обуславливают и способствуют осознанному выбору многодетности супругов. На базе теоретического анализа была разработана анкета и осуществлен опрос, который включал несколько существенных блоков - вопрос о принятии решения о многодетности, относительно трудностей многодетной семьи, особенностей внутрисемейной и социальной поддержки.

Результаты. Теоретически и эмпирически выявлены социальнопсихологические особенности людей, которые сознательно стали родителями 3$\mathrm{x}$ и более детей и чувствуют в этом свое призвание, потребность и желание, основанные на высоких репродуктивных начальных установках у большинства респондентов. Установлено, что переход семьи в многодетность может осуществляться различными этапами, в тоже время можно утвердительно говорить, что осознанную многодетность следует рассматривать как запланированную многодетность. Это подтверждается данными статистики и социокультурными механизмами, в частности наличие 3 -х и более детей является тем уровнем, который обуславливает жизнеспособность общества и семьи.

Проанализированы данные опроса благополучных многодетных семей, где наблюдается жизненная стойкость семейной системы, женщины занимаются профессиональной деятельностью, самореализованы, и при этом сочетают материнство и воспитание детей, ведь в современном мире ценность родительства конкурирует с другими ценностями, в том числе с успешной профессиональной деятельностью и карьерой. Установлены определенные общественные установки и стереотипы относительно многодетности. Приведены современные точки зрения общества, согласно которым предназначение женщины - это не только материнство и дом, но и другие возможности для реализации заложенного в ней потенциала. Основой сознательной многодетности супругов является личностная и социальная зрелость его членов.

Выводы. В работе сформулированы социальные и личностные характеристики, проблемы и трудности, с которыми сталкиваются родители с сознательной многодетностью. Доказано, что социальная поддержка хотя и играет существенную роль, но прежде всего нужно формировать ее на базе психологической готовности, сознательного выбора, возможностей самореализации таких семей и родителей в частности. 
Ключевые слова: семья, супруги, родительство, психологическая готовность, самореализация родителей.

Вступ. На сьогоднішній день багатодітність як соціальнопсихологічний феномен вивчається 3 позицій різних наук і підходів як багатовимірне явище, яке $\epsilon$ результатом впливу внутрішніх (породжених соціально-психологічною сутністю самої людини, іiі уявленнями й установками) факторів і зовнішніх (соціокультурних).

Вітчизняний педагог А. С. Макаренко вперше звернув увагу на кількість дітей у сім’ї і зв’язок з цим фактом виховання дітей в такій родині. Науковець вважав сім'ю колективом і радив не обмежуватись народженням однієї дитини навіть якщо в сім’ї мають місце деякі матеріальні труднощі (Макаренко, 1987.).

Згідно з Законом України «Про охорону дитинства» багатодітна сім'я - це сім'я, в якій подружжя (чоловік та жінка) перебуває в зареєстрованому шлюбі, разом проживають та виховують трьох i більше дітей, зокрема й кожен із подружжя, або один батько (одна мати), який (яка) проживає разом із трьома i більше дітьми та самостійно їх виховує. До складу багатодітної сім’”̈ належать також діти, які навчаються за денною формою навчання у загальноосвітніх, професійно-технічних та вищих навчальних закладах - до закінчення навчальних закладів, але не довше, ніж до досягнення ними 23 років.

Традиційно багатодітність як аспект народжуваності виступав предметом вивчення демографії, однак протягом останнього століття відбулися не лише соціально-економічні зміни щодо народжуваності і сім’ї загалом, а й психологічні (Ананьєва, 2015). Якщо брати до уваги основну масу людей, то за останнє століття матеріальний стан покращився в десятки разів, у людей з'явилася можливість отримати освіту, купити житло, немає проблем з одягом і їжею. Водночас аналіз умов життя сімей показав: чим краще матеріальні і житлові умови, тим частіше в родині установка на народження однієї дитини. I тут уже переважають психологічні особливості сімей, які проявляються у захисті своїх інтересів і достатку, у недовірі життю, покладанні на власні сили.

Тобто можна передбачити, що репродуктивна установка сім’̈ багато в чому пов'язана з суб'єктивною оцінкою подружжям свого матеріального становища. Цікаво, що в найбільш забезпечених сім'ях третина подружніх пар (частіше - чоловіки) вважають матеріальні 
умови недостатніми і розцінюють це як перешкоду до появи дитини (Бодров, А. В., Боярова, О. А., 2016). А сім'ї, де дохід невеликий і вже $є$ одна або дві дитини, але матеріальне становище значно нижче, ніж у забезпечених сім'ях, оцінюють своє матеріальне становище як достатнє. Отже, яким би не був дохід сім'ї, задоволеність ним може бути різною. Значною мірою вона визначається тим, яке місце займають матеріальні блага в системі цінностей сім’ї. Тобто діти немов би вступають в конкуренцію із задоволенням матеріальних потреб їхніх батьків. Якщо матеріальні потреби високі, то дитина не витримує конкуренції. Тобто сучасні люди, які стали жити набагато краще - стали в той же час набагато обережнішими у плануванні життя. Це з одного боку. 3 іншого - розповіді попередніх поколінь щодо важкого життя 3 дітьми і неможливість реалізації жінки/матері у професійному плані стають перепоною та страхом і до сьогодні (Чепелєва, 2020). А ще часто згадки про поганий матеріальний стан це лише прикриття простого небажання мати більше ніж «прийнято» дітей.

Багатодітні сім’ї можна розподілити за типами. Наприклад, науковці І. Д. Звєрєва та Г. М. Лактіонова розрізняють такі типи багатодітних сімей (Звєрєва, 2008):

1. Сім’ї, в яких батьки свідомо хотіли мати декількох дітей, дуже люблять своїх дітей, хочуть проводити з ними час. У цій категорії людей діти - це життєва цінність, і батьки роблять усе від них залежне для благополуччя сім’і і дітей.

2. Сім’ї, де батьки свідомо не прагнули мати багато дітей. Такі діти могли з'явитися через відсутність планування сім'ї (випадкова багатодітність). Тому такі сім’ї можуть сформуватися в результаті народження двійні чи трійні, відмови від засобів контрацепції через релігійні переконання тощо.

3. Сім’ї, які утворилися в результаті другого чи наступного шлюбів матері чи батька, в яких народилися нові спільні діти.

4. Сім’ї, в яких народження великої кількості дітей можна вважати проявом неблагополуччя. Діти $є$ засобом для отримання різного роду пільг та благ. Крім того, у більшості випадків у таких сім'ях сама поява дітей на світ є наслідком невпорядкованих статевих стосунків у стані алкогольного чи наркотичного сп'яніння (Карпінець, Кіндратюк, Ковальчук, 1995). 
У цій статті не розглядатимуться неблагополучні багатодітні

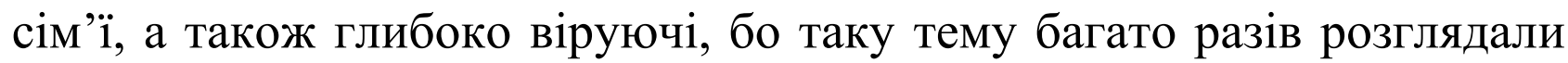
науковці. У таких сім'ях часто не стоїть питання самосвідомості i бажання стати багатодітними батьками. Завдання нашої статті зробити спробу систематизувати психологічні особливості тих людей, які хочуть свідомо стати багатодітними батьками і можуть поєднувати цю місію з самореалізацією і професійним розвитком.

Проблемі наукового вивчення багатодітності та батьківства у сучасній психології присвячено досить багато робіт (Красін, 2017; Фадєєв, Лемещенко 2013). 3 появою дітей у сім’ї подружжя свідомо чи несвідомо вступають у новий статус - батьків. Однак необхідно відзначити, що біологічна здатність бути батьком не завжди відповідає сформованій психологічній готовності до виконання батьківських ролей, яка формується під впливом різних факторів i виражається в усвідомленні себе батьками і способах реалізації батьківської ролі (Bradbury, Rogge, 2010). I найбільш гостро це проявляється в багатодітності. Батьківство виражається у відповідальності, що визначає поведінку батьків і має дуальну природу: відповідальність перед собою, дітьми і суспільством у питаннях духовного і фізичного розвитку дітей (Дружинін, 1996). Зауважимо, що ослаблення репродуктивної поведінки родин зумовлено тим, що народження третього і наступних дітей часто сприймається всупереч панівним в сучасному суспільстві стереотипним нормам малодітності. Цікава точка зору А. І. Антонова про те, що раніше причиною формування установки на багатодітність була економічна мотивація дітонародження, яка полягає в економічній корисності великої кількості дітей, наприклад як «робочих рук» (Антонов, 2001). М. С. Мацковський і П. А. Сорокін вважають, що на сучасному етапі розвитку інституту сім’і економічний фактор народжуваності втратив своє значення, відбулася його заміна на соціально-психологічне значення для батьків (Мацковський, 1989, Сорокін, 1997). Тобто заміна на потребу чи небажання мати більше дітей, ніж це «прийнято» у суспільстві. Отже, багатодітність можна визначити як соціокультурний, психологічний та економічний феномен, основу якого становить запланована репродуктивна поведінка, зокрема й потреба індивідів мати 3-х і більше дітей, яка виходить із культурно-моральних, національних та релігійних стереотипів і норм. 
Мета статті. Теоретично й емпірично виявити соціальнопсихологічні особливості людей, які свідомо стали батьками 3-х і більше дітей та відчувають у цьому своє покликання, потребу i бажання.

Значущість питання обумовлена тим, що з соціальної точки зору наявність однієї дитини або бездітність призводить до згасання родини і скорочення суспільства, наявність 2-х дітей лише відтворює родину і соціум, і тільки наявність 3-х дітей дає можливість спільноті зростати, родині розширюватись. Тому саме наявність 3-х і більше дітей є тим рівнем, який зумовлює розростання родини і суспільства. Отже, багатодітність - це не тільки соціокультурний і психологічним феномен, а механізм життєздатності суспільства й родини.

Методи та процедура дослідження. Проведено теоретичний соціально- психологічний аналіз феномену багатодітності, виділено характеристики, які зумовлюють, сприяють свідомому вибору багатодітності подружжя. На базі теоретично виокремлених особливостей свідомої багатодітності було розроблено анкету, яка включала декілька сутнісних блоків - блок питань щодо прийняття рішення про багатодітність, блок питань щодо труднощів багатодітної родини, блоки особливостей внутрішньосімейної та соціальної підтримки. У ході нашого дослідження було опитано 37 батьків багатодітних родин, які свідомо народили 3-х і більше дітей, при цьому жінки у цих сім'ях самореалізовані, працюють і поєднують материнство з саморозвитком. Під час дослідження було виявлено, що перехід сім’ї до багатодітності може здійснюватися різними етапами. Можна сказати, що більшість опитаних нами у своїх початкових установках 3 самого початку зародження сім’ї не планували народження 3-x і більше дітей, але допускали такі думки. Такі батьки мають свідоме ставлення до планування народження (тобто батьки в процесі всього репродуктивного віку ретельно планують народження дітей).

Щодо ж мотивації стати багатодітною родиною, то 74\% опитаних мали високий рівень початкових репродуктивних установок, тобто допускали думки стати багатодітною родиною. Можна з упевненістю сказати, що усвідомлену багатодітність слід розглядати як заплановану багатодітність.

Обговорення результатів. Під багатодітністю, згідно 3 законодавством України, слід розуміти сім’ю, в якій разом 
проживають батьки та троє і більше дітей, до речі, ще 50 років тому така сім'я вважалася середньодітною. При цьому можна говорити про неоднорідність багатодітних сімей - діти в таких сім'ях можуть бути кровними, зведеними i прийомними. Зниження народжуваності i кількості дітей в сім’ї призвело до зміни змісту поняття багатодітності. Серед найбільш важливих факторів, що вплинули на зміну феномена багатодітності в сучасних умовах, на наш погляд, виступають урбанізація та індустріалізація, які спричинили за собою трансформацію ролі жінки і сім’ї в суспільстві, в тому числі зміна гендерних ролей, ставлення до дітей. У минулому, зазвичай, багатодітні сім’ї утворювались через потребу у робочій силі або через низькі можливості у плануванні сім'ї, щодо сучасного життя, то багатодітність все більше стає усвідомленою, тобто в подружжя виникає саме потреба в розширенні родини.

На основі нашого аналізу, проведеного з багатодітними батьками, то більшість відповіли (71\%), що мають достатній рівень матеріальної забезпеченості, а також наявність близьких родичів i членів сім’ї, готових надавати допомогу з дітьми. Щодо батьків, то зі збільшенням кількості дітей у сім’ї збільшується і батьківський досвід, який дозволяє оптимально для ситуації поєднувати професійні справи з вихованням дітей.

Опитані нами батьки багатодітних родин, а саме $84 \%$ відповіли, що мають дуже добре стосунки між собою (як подружжя), розуміють один одного з півслова, мають однакові установки та погляди на виховання дітей, тобто згуртованість батьків, взаєморозуміння, кохання стають основою благополучної багатодітної родини. Серед опитаних нами родин всі чоловіки повністю залучені до процесу виховання, починаючи від вагітності та допомоги жінці у цей період, присутності на пологах, піклування про дитину в період раннього дитинства та подальшого дорослішання дітей.

Щодо татусевої реалізації, то серед опитаних нами чоловіків всі татусі працюють або по найму або приватні підприємці. В плані кар'єрного зростання чоловікам простіше, бо їм не треба виношувати i народжувати дитину, але в плані забезпечення родини на багатодітних татусях лежить більша відповідальність. Тому батькичоловіки таких сімей - це зрілі самодостатні люди, різнобічно розвинені, 3 глибоким позитивним настроєм на життя, які усвідомлено прийшли до бажання мати велику сім'ю, з мотивацією і 
відповідальністю. Більшість чоловіків цієї категорії вважають основним критерієм виховання дітей - власний приклад, позитивну мотивацію, рівність серед дітей.

Зрозуміло, що сучасний інститут батьківства зазнає суттєвих змін. У нових умовах цінність батьківства для індивідів, що виражається в дітоцентричності, конкурує 3 іншими цінностями, зокрема з успішною професійною діяльністю і кар'єрою. У зазначеній ситуації рішення про народження більшого числа дітей стає максимально усвідомленим вибором індивідів.

На сьогодні вельми актуальною $\epsilon$ проблема жіночої самореалізації. Це бажання багато в чому спровоковане сучасними суспільними стереотипами. Зрозуміло, що жінка, яка віддає час роботі, не може повністю встигати вести господарство і піклуватися про дітей, особливо коли їх декілька, як це закладено традиційною культурою і ролями, отже, одна з цих двох важливих сфер все одно постраждає. Тому багато жінок беруть у дім помічницю, а для дітей няню, не менш цінною $є$ i підтримка 3 боку суспільства (дитячі заклади, муніципальна няня, пільги). Це нормальне явище, яке ще й дозволяє дитині більше цінувати матір як соціально успішну жінку. Але поєднання багатодітності й успішної кар'єри - дві речі, що збігаються в дуже рідкісних випадках.

Щодо ж опитаних нами родин, то $81 \%$ жінок у цих умовах поєднують роботу з домашніми обов'язками і вихованням дітей. Наведемо приклади, як це відбувається. Як уже було сказано, більшість сімей має помічниць, нянь, бабусь, які на постійній основі допомагають матері відвідати поліклініку, забрати дитину з садочка, школи, допомогти з уроками тощо, коли мати зайнята роботою. Щодо ж самих професій, то здебільшого це професії, де можна обирати більш вільний графік роботи (лікар, перукар, вчитель, фітнес-тренер, програміст, фрілансер з віддаленою формою роботи через Інтернет), ніж професії з високою регламентованістю і прив'язкою до місця роботи. До того ж деякі жінки працюють неповний робочий день. Отже, з цього важливого пункту можна зробити висновок, що сильна психологічна мотивація, бажання мати дітей не стають на заваді таким родинам, вони запускають механізми пошуку професій 3 нестандартним графіком роботи і реалізації себе.

Наступним аспектом, який впливає на багатодітність, є здоров'я жінки. Виношування, пологи, годування, виховання дітей вимагають 
від жінки величезної енергії. У нашому випадку - опитані нами жінки - це в загальному розумінні здорові жінки, які не мають серйозних фізичних вад, ускладнень у гінекологічній та в інших сферах здоров'я.

Ще одним важливим питанням, яке впливає на рівень прийняття таких родин - це ставлення соціуму й оточення. Багато людей засуджують багатодітність та пов'язують її з неблагополучністю або ж із релігійним фанатизмом, що деякою мірою має сенс, але не все так однозначно. Часто в таких родинах це або «особлива» відзнака, або майже єдине «досягнення», через які вони сприймаються. Водночас серед людей з високим рівнем достатку багатодітність теж доволі розповсюджене явище, але сприймаються ці люди і родини не через фактор багатодітності, а через рівень життя, залишаючи родину на другому плані. Але так склалися сучасні стереотипи в суспільстві, що основна частина людей вважає багатодітність відхиленням, майже психічним захворюванням, тому багатодітні батьки все своє життя стикаються $з$ непорозумінням з боку людей, суспільства, влади. Це велике, важке і несправедливе випробування.

Підтверджується це й статистичними даними. Згідно з офіційною статистикою Міністерства соціальної політики всього в Україні 333187 тис. багатодітних сімей, 3 них 102,3 тис. малозабезпечених багатодітних родин. А отже, більшість багатодітних сімей все ж таки свідомо йдуть на народження наступної дитини і можуть собі дозволити їі виховати в нормальних умовах життя, достатку, сімейнородинних стосунків.

Щодо соціального захисту багатодітних сімей в Україні, незважаючи на постійне підвищення прожиткового мінімуму на дитину та допомогу при іiї народженні, показник соціального захисту у нашій країні станом на 2019 рік був у декілька разів нижчий, порівняно з країнами СС. Найвищі витрати на соціальний захист були в Данії (33,4\%), Франції (33,1\%), Швеції (32,1\%), Нідерландах $(31,6 \%)$ та Німеччини $(31,4 \%)$; найнижчі (менш ніж 20\%) - у Польщі, Естонії, Словаччині, Болгарії, Румунії та Латвії. У світовій практиці лише Мексика, Туреччина, Бразилія та Аргентина мало допомагають сім'ям із дітьми. Частка витрат на соціальний захист та допомогу в цих країнах не перевищує 5\% від ВВП. Але й це, на жаль, більше, ніж в Україні. 
Але слід зауважити, що незважаючи на суттєву підтримку державами народжуваності, це не єдиний показник, який визначає мотивацію багатодітності. Так, наприкінці XX - на початку XXI ст. швидкими темпами відбувається процес скорочення населення в усіх країнах Свропейського Союзу. Показник сумарної народжуваності на рівні 1,1 - 1,2 дитини на одну жінку спостерігається у Чехії, Іспанії, Словенії, у Німеччині - 1,3. Ці країни вдаються до практики стимулювання народжуваності в тих родинах, які вже мають дітей та бажають збільшити їх чисельність. Отже, європейські країни намагаються зберегти рівень відтворення населення за рахунок стимулювання багатодітності (Захарова, 2012).

Доцільно зауважити, що коефіцієнт фертильності, тобто кількість дітей, народжених однією жінкою в середньому в Україні становить 1,3 (як і в Німеччині).

Згідно зі статистичними даними Міністерства соціальної політики України, станом на 01.02.2018 в Україні налічувалося більше 16 млн сімей, з них 333187 багатодітних сімей. Тому можна зробити висновок, що багатодітна сім'я попереджає розвиток демографічної кризи і має великий досвід у реалізації виховної функції, адже діти отримують природні умови сімейної соціалізації особистості. В благополучній багатодітній родині великий досвід спілкування з братами, сестрами, батьками, а отже, є позитивний досвід любові, спілкування, поваги, витримки, розподілу загальної радості та загальної напруги.

Наступний крок - процес виховання в багатодітній родині, який досить суперечливий. Часто в таких сім'ях батьки можуть втрачати почуття рівності стосовно дітей та приділяти увагу їм різною мірою. Всі діти, незалежно від віку, потребують уваги, але чим менші брати та сестри, тим більше уваги батьків вони забирають на себе, тому старшим дістається менше, і тоді вони по-своєму реагують на це: в одних випадках проявляється тривожність, почуття неповноцінності та невпевненість у собі, в інших - підвищена агресивність, неадекватна реакція на сімейні ситуації. Щодо старших дітей, то вони можуть бути більш категоричні, прагнути до лідерства та домінування навіть тоді, коли для цього немає підстав. Все це ускладнює процес узгодження сімейної системи. В багатодітних родинах збільшене фізичне й психічне навантаження на батьків, особливо на матір. Багатодітна сім'я має менше можливостей для 
задоволення потреб та прояву уваги до інтересів дитини, яким і так приділяється значно менше часу, ніж у родині з однією дитиною, що, природно, може позначитися на розвитку дитини. Тому саме в цьому напрямку багатодітні сім’ї потребують соціальної підтримки й участі. Отже, успішність виконання багатодітною сім'єю виховної функції значною мірою залежить від виховних можливостей родини (Замашкіна, 2016).

Але негативні тенденції - це більше небезпека, ніж правило, гармонійна сімейна система багатодітної родини позитивно впливає на формування готовності дітей до народжуваності, що підтверджується наслідуваністю багатодітності в майбутніх поколіннях.

Це комплекс різних умов та засобів, до яких слід віднести: матеріальні та побутові умови, чисельність і структуру родини; моральний та емоційно-психологічний клімат сім’ї; рівень розвитку сімейного колективу та характер стосунків між його членами; трудову атмосферу сім’ї, життєвий досвід та культурно-освітній рівень членів сім’ї; наявність вільного часу та характер організації сімейного дозвілля; особистий приклад батьків; характер контакту сім'ї з навколишнім середовищем; рівень педагогічної культури дорослих членів сім’і; сімейні традиції; особливості професійного досвіду батьків тощо. Все це $\epsilon$ системою можливостей сім'ї 3 побудови усвідомленої благополучної багатодітної родини.

Висновки і перспективи. Отже, підбиваючи підсумки аналізу представлених підходів до розгляду усвідомленого батьківства i багатодітності, зазначимо, що в цих подружніх пар наявні певні соціально-психологічні особливості, які проявляються в покликанні, потребі і готовності мати більше дітей. Високий рівень психологічного благополуччя, гнучкості, особистісної та соціальної зрілості таких людей i закладає грунт усіх можливих проявів підтримки один одного в багатодітній родині. До того ж уміння знайти і поєднати роботу з сім'єю, відсутність у індивідів будь-яких істотних проблем зі здоров'ям, уміння протистояти суспільному тиску, налагодження стосунків 3 іншими членами родини, які теж можуть надавати своєчасну допомогу та підтримку. Своєрідна згуртованість і дає ту позитивну основу для виникнення такого поняття, як успішна, психологічно й матеріально благополучна багатодітна родина. I безперечно потребує подальшого дослідження 
психологічний стан дітей з багатодітних благополучних родин, їх установки щодо своєї репродуктивної ролі у суспільстві в майбутньому.

Наші наукові розробки й емпіричні дані підтверджують, що соціальна підтримка хоча й грає суттєву роль, але не є визначальною при свідомій багатодітності. Її насамперед потрібно формувати на базі психологічної готовності, свідомого вибору та особливо можливостей самореалізації таких сімей і батьків зокрема. Тобто потрібно здійснювати не просто підтримку і стимулювання, а саме популяризацію багатодітності, адже з соціальної точки зору наявність трьох і більше дітей - це не стільки багатодітність скільки норма, яка закладає життєздатність родини і спільноти.

\section{Лiтература}

1. Ананьева, Н. Н. (2015). Субкультура многодетной семьи в современном обществе. Вестник славянских культур, 3 (37), 99-104.

2. Антонов, А. И., Медков, В. М. (1996). Социология семьи. Москва: Издво Моск. ун-та.

3. Бодров, А. В., Боярова, Е. А. (2016). Образ многодетной семьи в зеркале общественного мнения. Вестник Саратовскогого государственного соииально-экономического университета, 5 (64), 84-89.

4. Дружинин, В. Н. (1996). Психология семьи. Москва: КСП.

5. Замашкіна, О. Д. (2016). Комплексний підхід щодо соціальної підтримки молодих сімей. Соціальна робота в Україні: теорія і практика, 1-2, $77-85$.

6. Захарова, Е. И. (2012). Представление о характере социальной роли, как средство ориентировки в ее исполнении. Культурно-историческая психология, 4, 38-41.

7. Звєрєва, І. Д. (2008). Книга для батьків. Київ: ДЦСССДМ.

8. Красін, С. А. (2017). Усвідомлене батьківство: сутність, ознаки, структура та зміст. Педагогіка формування творчої особистості у вищій i загальноосвітній школах, 55, 215-221.

9. Макаренко, А. С. (1987). Собрание сочинений. Москва: Правда.

10. Мацковский, М. С. (1989). Социология семи: проблемы методологии и методики. Москва: Наука.

11. Сорокин, П. А. (1997). Кризис современной семьи. Вестник МГУ. Социология и политология, 3, 65-79.

12. Фадєєв, В. І., Лемещенко, О. Р. (2013). Усвідомлене батьківство: сучасна модель сім'ї. Проблеми сучасної педагогічної освіти. Педагогіка $i$ психологія, 38(1), 165-170. 
13. Чепелєва, Н. І. (2020). Трансформація уявлень жінок під час очікування дитини як чинник адаптації до материнства. Теорія i практика сучасної психології, 1(3), 121-126.

14. Apsley, H. B., \& Padilla-Walker, L. M. (2020). Longitudinal links between parents' mental health, parenting, and adolescents' mental health: Moderation by adolescent sex. Journal of Family Psychology, 34(7), 886-892. DOI: https:// doi.org/10.1037/fam0000788

15. Bradbury, T. N., Rogge, R., \& Lawrence, E. (2010). Reconsidering the role of conflict in marriage. NJ.: Erlbaum, 44-65.

16. Fincham, F. (2003). Marital Conflict: Correlates, Structure, and Context. Current Directions in Psychological Science, 12(1), 23-27.

17. Grych, J. H., Fincham, F. D. (2001). Interparental conflict and child development: Theory, research, and applications. New York: Cambridge University Press. DOI: https://doi.org/10.1017/CBO9780511527838

\section{References}

1. Ananeva, N. N. (2015). Subkultura mnogodetnoy semi v sovremennom obschestve [The subculture of a large family in modern society]. Vestnik slavyanskih kultur - Bulletin of Slavic Cultures, 3 (37), 99-104 [in Russian].

2. Antonov, A. I., Medkov, V. M. (1996). Sotsiologiya semi [Sociology of the family]. Moskva: Izd-vo Mosk. un-ta [in Russian].

3. Bodrov, A. V., Boyarova, E. A. (2016). Obraz mnogodetnoy semi v zerkale obschestvennogo mneniya [The image of a large family in the mirror of public opinion]. Vestnik Saratovskogogo gosudarstvennogo sotsialno-ekonomicheskogo universiteta - Bulletin of the Saratov State Social and Economic University, 5 (64), 84-89 [in Russian].

4. Druzhinin, V. N. (1996). Psihologiya semi [Family psychology]. Moskva: KSP [in Russian].

5. Zamashkina, O. D. (2016). Kompleksnyi pidkhid shchodo sotsialnoi pidtrymky molodykh simei [An integrated approach to social support for young families]. Sotsialna robota v Ukraini : teoriia i praktyka - Social work in Ukraine: theory and practice, 1-2, 77-85 [in Ukrainian].

6. Zaharova, E. I. (2012). Predstavlenie o haraktere sotsialnoy roli, kak sredstvo orientirovki $\mathrm{v}$ ee ispolnenii [The idea of the nature of a social role as a means of orientation in its performance]. Kulturno-istoricheskaya psihologiya Cultural-Historical Psychology, 4, 38-41 [in Russian].

7. Zvierieva, I. D. (2008). Knyha dlia batkiv [A book for parents]. Kyiv: DTsSSSDM [in Ukrainian].

8. Krasin, S. A. (2017). Usvidomlene batkivstvo: sutnist, oznaky, struktura ta zmist [Conscious parenting: essence, signs, structure and content]. Pedahohika formuvannia tvorchoi osobystosti u vyshchii i zahalnoosvitnii shkolakh - Pedagogy of formation of creative personality in higher and secondary schools, 55, 215-221 [in Ukrainian]. 
9. Makarenko, A. S. (1987). Sobranie sochineniy [Collected Works]. Moskva: Pravda [in Russian].

10. Matskovskiy, M. S. (1989). Sotsiologiya semi: problemyi metodologii $i$ metodiki [Sociology of Seven: Problems of Methodology and Technique]. Moskva: Nauka [in Russian].

11. Sorokin, P. A. (1997). Krizis sovremennoy semi [The crisis of the modern family]. Vestnik MGU. Sotsiologiya i politologiya - Moscow State University Bulletin. Sociology and Political Science, 3, 65-79 [in Russian].

12. Fadieiev, V. I., Lemeshchenko, O. R. (2013). Usvidomlene batkivstvo: suchasna model simi [Conscious parenting: a modern model of the family]. Problemy suchasnoi pedahohichnoi osvity. Pedahohika i psykholohiia - Problems of modern pedagogical education. Pedagogy and Psychology, 38(1), 165-170 [in Ukrainian].

13. Chepelieva, N. I. (2020). Transformatsiia uiavlen zhinok pid chas ochikuvanni dytyny yak chynnyk adaptatsii do materynstva [Transformation of women's perceptions while expecting a child as a factor of adaptation to motherhood]. Teoriia i praktyka suchasnoi psykholohii - Theory and Practice of Modern Psychology, 1(3), 121-126 [in Ukrainian].

14. Apsley, H. B., \& Padilla-Walker, L. M. (2020). Longitudinal links between parents' mental health, parenting, and adolescents' mental health: Moderation by adolescent sex. Journal of Family Psychology, 34(7), 886-892. DOI: https:// doi.org/10.1037/fam0000788

15. Bradbury, T. N., Rogge, R., \& Lawrence, E. (2010). Reconsidering the role of conflict in marriage. NJ.: Erlbaum, 44-65.

16. Fincham, F. (2003). Marital Conflict: Correlates, Structure, and Context. Current Directions in Psychological Science, 12(1), 23-27.

17. Grych, J. H., Fincham, F. D. (2001). Interparental conflict and child development: Theory, research, and applications. New York: Cambridge University Press. DOI: https://doi.org/10.1017/CBO9780511527838

Received: 05.05.2021

Accepted: 18.05.2021 